\title{
Impacts of invasive annual grasses and their litter vary by native functional strategy
}

\author{
Marina L. LaForgia $(\mathbb{D}$
}

Received: 11 July 2020/Accepted: 8 April 2021/Published online: 28 April 2021

(C) The Author(s) 2021

\begin{abstract}
Invasive species may act as a functional filter on native communities by differentially affecting species with different trait values. Across environments, invasive plants typically display traits associated with high resource acquisition and fast growth. Conversely, native plants, especially those in waterlimited environments, tend to adopt one of two functional strategies: fast growth during high resource availability to avoid stress (resource-acquisitive), or slow growth during resource-poor conditions to tolerate stress (resource-conservative). While invasive competition can be a strong filter on these groups, many invaders also alter the structure of native communities through their accumulation of litter. How fast-growing invaders with litter shift native functional communities remains unknown. To elucidate these functional shifts, I manipulated invasive annual grasses and their litter in an annual grassland and followed the demographic rates of six native annual forb species that varied in their functional strategy. Live grass competition alone decreased per capita growth rates of resource-acquisitive natives and had no effect on resource-conservative natives. The
\end{abstract}

Supplementary Information The online version contains supplementary material available at https://doi.org/10.1007/ s10530-021-02527-2.

M. L. LaForgia ( $₫)$

Department of Evolution and Ecology, University of

California, Davis, Davis, CA, USA

e-mail: marina.laforgia@gmail.com presence of litter, however, decreased growth rates in both functional types of natives, with stronger declines in resource-acquisitive species through differential effects on seed set and germination. Invaders in this system thus create an unfavorable environment for natives through litter, limiting the capacity of both resource-acquisitive and resource-conservative native forbs to maintain high population growth. These findings suggest that grass invasions have the potential to dramatically shift the functional composition of native communities through the time-lagged effects of their litter.

Keywords Annual grassland $\cdot$ Litter $\cdot$ Functional strategy $\cdot$ Invasive annual grass $\cdot$ Native annual forb

\section{Introduction}

Invasive plants impose a novel biotic filter on their native neighbors by altering the availability of key resources (Richardson and Pysek 2006; Ehrenfeld 2010), which can lead to declines in biodiversity (Mack et al. 2000) and shifts in an ecosystem's structure and function (Vitousek et al. 1997; Ehrenfeld 2010). The impacts of this novel filter depend on the competitive abilities and resource acquisition strategies of the species in the community (Goldberg and Landa 1991; Chapin et al. 1993; Goldberg 1996). 
Many invasive plants are competitively dominant over natives (Levine et al. 2003; Corbin and D'Antonio 2010; Schultheis and MacGuigan 2018) and tend to display functional traits associated with fast resource acquisition (Leishman et al. 2007; van Kleunen et al. 2010; Lagos et al. 2017), such as high relative growth rates, fast maturations, and high specific leaf areas (SLA; leaf area/leaf mass). However, we know less about the traits that make individual native species vulnerable to invasives, and still less about how the functional diversity and composition of native communities is transformed by the filter of invasive species (Gubsch et al. 2011; Price and Pärtel 2013; Mitchell and Bakker 2016).

While fast resource acquisition is a common invader strategy across many environments, native plants in seasonally water-limited climates typically exhibit one of two functional strategies: either growing slowly to conserve water and thereby tolerate lower resource levels (resource-conservative strategy), or growing quickly to usurp available resources and attempt to avoid stressful conditions, but at the cost of being more sensitive to changes in resource availability (resource-acquisitive strategy) (Brown and Venable 1986; Angert et al. 2007). Resourceconservative plants display traits like low specific leaf areas, low relative growth rates, deep roots, large seeds, and high water use efficiency, while resourceacquisitive species tend to have the opposite trait values (Wright et al. 2004; Diaz et al. 2004; Reich 2014). These alternative strategies contribute to coexistence in water-limited environments (Angert et al. 2009) and have contrasting ecosystem-level effects (Lavorel and Garnier 2002). Broadly, ecosystems with higher proportions of resource-acquisitive species are more productive and display faster nutrient cycling due to their more labile leaf litter (Lavorel and Garnier 2002; Cornwell et al. 2008). Conversely, ecosystems where resource-conservative species predominate have slower nutrient turnover, but these plant communities may be less demographically variable over time (Huxman et al. 2008) and more resistant to disturbances (MacGillivray et al. 1995). A key component of predicting how ecosystems are reshaped by invasions is understanding whether invaders have stronger effects on species with one of these two strategies, thereby shifting the functional composition of remnant communities.
There is already some evidence to suggest that invaders disproportionately affect resource-acquisitive natives over resource-conservative natives. For instance, as acquisitive natives and invaders both rely on fast resource acquisition, competitively dominant invaders may have stronger negative effects on these functionally similar, but competitively inferior species (Fargione et al. 2003; Emery 2007; Cleland et al. 2013; LaForgia et al. 2020). Conservative natives, on the other hand, may be less sensitive to invaders due to niche partitioning driven by differences in resource acquisition strategies that promote their coexistence (Fargione and Tilman 2005; MacDougall et al. 2009). Furthermore, their tolerance of resource reduction may also make them more tolerant of resource reductions caused by competition (Goldberg and Landa 1991; Carmona et al. 2019). Notably, in water-limited systems competitive dominance may actually be associated with resource-conservative traits including lower SLA, later flowering phenology, and deeper roots (Godoy and Levine 2014; Kraft et al. 2015). Despite this, many of these systems are heavily dominated by fast-growing invaders with resourceacquisitive traits. Therefore, while dominance of invaders over competitively inferior, fast-growing natives may be predicted by differences in competitive ability, it remains unclear why fast-growing invaders in some water-limited systems maintain dominance over conservative natives. Importantly, the majority of previous studies focus on competition between live plants, but many invaders affect native communities through other pathways as well, such as through their production of litter (Facelli and Pickett 1991). Exploration of these alternative pathways may help explain invader dominance in situations where competition alone is insufficient.

California annual grasslands are a highly variable and water-limited system dominated in biomass by a handful of invasive annual grass species. These grasses have high germination rates, high relative growth rates, and prolific seed output (Bartolome 1979; Dyer and Rice 1999), leading to dense, low richness communities of primarily grass across the landscape. Their dominance has irreversibly altered the structure and species composition of these communities (D'Antonio and Vitousek 1992), causing declines in richness and cover of less abundant native forbs (Davies 2011; Bennett et al. 2014; Case et al. 2016). Throughout winter and spring, live grass 
competes with the more functionally diverse native forbs for light, water, and nutrients, but the effects of grasses are not confined to this period. Invasive grasses, which are responsible for the majority of plant productivity in this system (Huenneke et al. 1990), dry out over the summer and create a vast carpet of thick litter that affects native forbs throughout the year.

Litter imposes a different set of filters on the native community than competition alone due to the ways in which litter and live plants alter resources, along with the temporal nature of those changes. Litter can be harmful to native plants by reducing light levels (Facelli and Pickett 1991; Chen et al. 2018), acting as a mechanical barrier to growth (Facelli and Pickett 1991), influencing soil chemistry by shifting nutrient availability (Ehrenfeld 2003; Farrer and Goldberg 2009) and releasing leachates (Loydi et al. 2015), and changing soil biota in favor of invasives (Zhang et al. 2019). Litter can also stabilize temperature fluctuations (Heady 1956) and increase soil moisture (Wolkovich et al. 2009), but its negative effects tend to outweigh these small benefits (Xiong and Nilsson 1999). While the importance of these various pathways varies depending on the properties of the invader and the environment, light limitation might predominate in California grasslands where highly productive invasive grasses accumulate large quantities of litter (Coleman and Levine 2007; Amatangelo et al. 2008; Chen et al. 2018; Molinari and D'Antonio 2020). A thick litter layer that is present prior to germination fundamentally changes the environment for germinating seeds and increases competition for light during growth more than live plants without litter. These strong and persistent effects can lower germination (Xiong and Nilsson 1999; Chen et al. 2018), increase mortality (Silva et al. 2018), and reduce seed set (Schramm and Ehrenfeld 2010). Conversely, live plants typically increase competition for resources, which intensifies as plants grow (Miriti 2006; Schiffers and Tielborger 2006), leading to declines in native biomass and decreases in seed set (Violle et al. 2006). Litter can therefore contribute disproportionately to native declines (Lamb 2008; Molinari and D'Antonio 2020). It remains unclear however how invaders and their litter differentially affect natives with contrasting functional strategies.

To understand how invasive grasses act as functional filters on native grassland communities, I manipulated live grass and grass litter and measured their effects on per capita population growth rates of six native annual forbs with variable functional strategies. Due to acquisitive species' high sensitivity to competition and resource availability, I predicted that (1) live invasive grasses alone would reduce the per capita population growth rates of resource-acquisitive forbs more than those of resource-conservative forbs. Further, because litter also has a large effect on resource availability, I predicted that (2) adding invasive grass litter would also have stronger effects on resource-acquisitive than resource-conservative forbs and that (3) these stronger effects on resourceacquisitive forbs would be seen at all life stages, including germination, survival (mortality) and seed set.

\section{Materials and methods}

Field site

The study site for this experiment was an annualdominated grassland in California's Inner North Coast Range at the University of California McLaughlin Natural Reserve (https://naturalreserves.ucdavis.edu/ mclaughlin-reserve). The site has a Mediterranean climate with cool, wet winters (December-March) and dry, hot summers (June-September). Annual precipitation averages $732 \mathrm{~mm}$ (1988 through 2018), but with annual levels ranging from 326 to $1427 \mathrm{~mm}$. Rainfall during the study year (2016-2017) was well aboveaverage (1297.87 mm; Knoxville Creek weather station, Western Regional Climate Center, www.wrcc. dri.edu/cgi-bin/rawMAIN.pl?caCKNO). These communities are dominated in biomass by invasive (Eurasian) annual grasses with native annual forbs making up a smaller percentage of cover but larger proportion of diversity. Dominant invasive grasses at the study site include Avena fatua L., Lolium multiflorum Lam., and Bromus hordeaceus L., with smaller abundances of Taeniatherum caput-medusae (L.) Nevski. One native annual grass, Vulpia microstachys (Nutt.) Munro, also occurs in small abundances at this site, however, none occurred within the study plots. 
Grass and litter manipulations

This study took place over the course of one growing season, from October 2016 through August 2017. In September 2016, prior to the initiation of the study, I established ten $30 \times 110 \mathrm{~cm}$ plots on a hillside of the study site with deep, serpentine-derived soils (high $\mathrm{Mg}$, low $\mathrm{Ca}$ ), which support both high invasive grass abundance and high native forb diversity. Within each plot I nested three $30 \times 30 \mathrm{~cm}$ subplots, each separated by a $10 \mathrm{~cm}$ buffer, in which I manipulated the presence of invasive grasses and their litter. At this time, litter from the 2015-2016 growing season (and live vegetation, of which there was little) was removed from all subplots. Each subplot within a plot was assigned to one of three treatments (see Online Resource 1: Fig. 1 for diagram of experimental design): (1) Removal of live invasive grasses ("no grass, no litter"), (2) No removal of live invasive grasses ("live grass, no litter"), and (3) No removal of live invasive grasses and addition of invasive grass litter ("live grass + litter"). Although these treatments do not allow me to disentangle the effects of litter alone from the combined effects of litter and grass, the "live grass + litter" treatment more closely resembles the natural state of these grasslands. This framework therefore allows for the comparison of how competition with live invaders differs from the true filtering effects of invasive grasses in this system.

To mimic naturally occurring litter in the "live grass + litter" treatment, invasive grass litter from the previous season was clipped from a similarly sized area at the experimental site and was placed over these subplots in October, prior to initiation of rains but after seeding native forbs. Litter was clipped to ensure unwanted plants were not obtained in the collection. Litter composition reflected the natural relative abundances of invasive grass species at the site and was made up of A. fatua, L. multiflorum, and B. hordeaceus with smaller amounts of $T$. caput-medusae. Litter was held in place with lightweight and flexible polypropylene bird netting, which has large enough holes for all plants to pass through $(\sim 2.5 \mathrm{~cm}$ apertures $)$ and is commonly used to limit wind-driven litter loss (Rotundo and Aguiar 2005; Farrer and Goldberg 2009; Mariotte et al. 2017; Wainwright et al. 2017). This remained in place until the end of the rainy season in April when the majority of litter had broken down and was replaced with live grass. This timing is also in agreement with litter decomposition rates of these grass species (Franck et al. 1997). Weeding of live grasses from the "no grass + no litter" subplots, along with weeding of all non-focal forbs from all subplots, started in November and occurred monthly

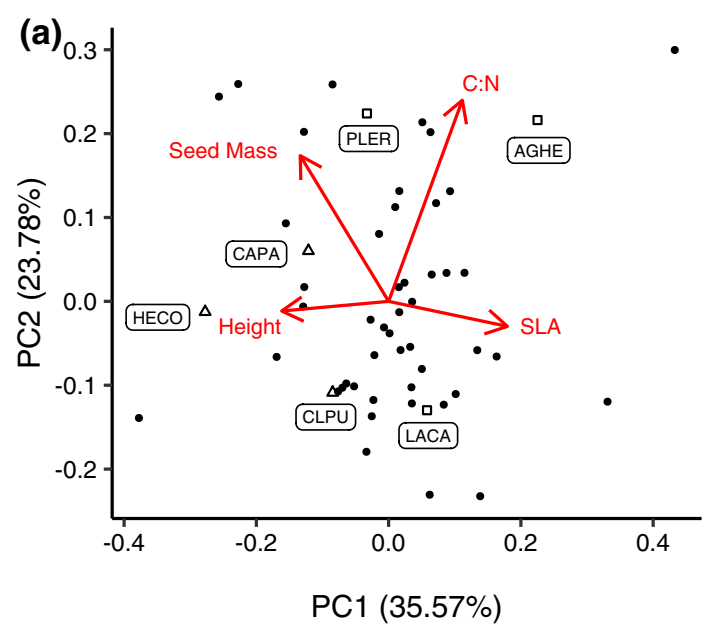

Fig. 1 a PCA ordination of 52 non-leguminous native annual forbs found on serpentine soils at the annual grassland site. Traits were collected on 10 individuals per species following standard protocols (see Fernandez et al. 2012). Study species are highlighted with acquisitive species as open squares and conservative species as open triangles. Species are identified

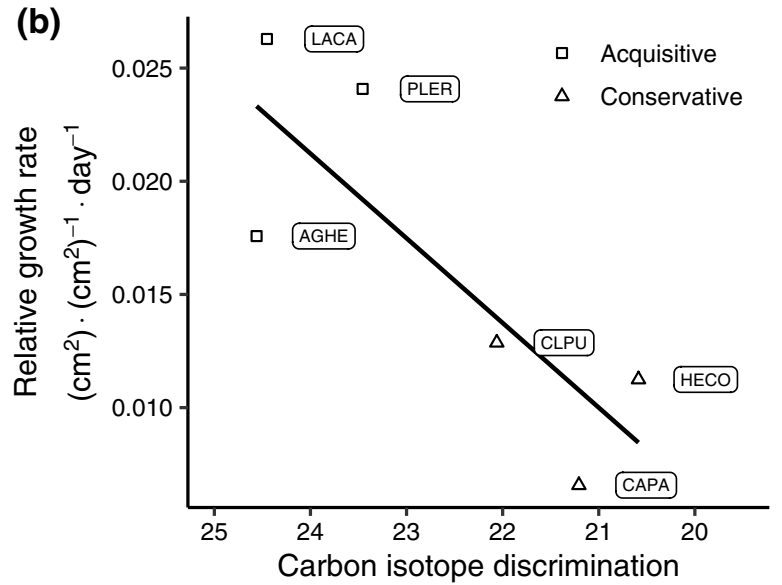

$$
(\Delta, \%)
$$

with a four-letter code: the first two letters of the genus and specific epithet. b Trade-off between relative growth rate (leaf area accumulation/time; $\mathrm{cm} \cdot \mathrm{cm}^{-1} \cdot \mathrm{day}^{-1}$ ) and intrinsic water use efficiency (carbon isotope discrimination; $\Delta, \%$ ) in the six study species. Adapted from LaForgia et al. (2020) 
until no invasive grasses or non-focal forbs were present in these respective subplots. Abundant, naturally occurring invasive grasses were allowed to germinate and grow in the "live grass, no litter" and "live grass + litter" treatments. Live invasive grass cover in the "live grass, no litter" and "live grass + litter" subplots was recorded during peak flowering for each species (April-June) and summed to obtain a total invasive grass cover per plot. Litter did not affect live invasive grass cover $(p=0.940)$, which averaged $68.5 \pm 8.4 \%$ (mean $\pm \mathrm{se}$ ) in the "live grass, no litter" treatment and $68.5 \pm 6.9 \%$ in the "live grass + litter" treatment.

Native forb selection and strategy assessment

I chose six common native annual forbs representative of a range of trait values observed in this community (Fig. 1a). This was assessed with a Principal Components Analysis, conducted using prcomp in the $\mathrm{R}$ package stats (R Core Team 2018), on SLA, height, seed mass, and $\mathrm{C}: \mathrm{N}$ ratio collected in a previous study (Fernandez-Going et al. 2012; for PCA results see Table 1 in the Online Resource 1). Species were Agoseris heterophylla (Nutt.) Greene, Clarkia purpurea (Curtis) A. Nelson \& J. F. Macbr., Lasthenia californica DC. ex Lindl., Plantago erecta E. Morris, Hemizonia congesta DC., and Calycadenia pauciflora A. Gray. Each species' resource acquisition strategy was previously characterized by measuring relative growth rate (RGR) and water use efficiency (WUE) on individuals from naturally occurring populations (LaForgia et al. 2020). Relative growth rate was measured by parameterizing a standard nonlinear growth model on leaf area accumulation over time on two individuals per species monthly in the field (Paine et al. 2012). Water use efficiency was assessed through leaf carbon isotope discrimination on fully mature young leaves collected from five individuals per species (Dawson et al. 2002). These two performance measures are correlated with widely studied morphological traits (SLA, seed size, and specific root length) (Reich et al. 1998; Westoby et al. 2002; Diaz et al. 2004; Angert et al. 2009; Harrison and LaForgia 2019) and are linked to population dynamics in other annual systems (Angert et al. 2007; Kimball et al. 2012). The species showed a standard tradeoff between relative growth rate and water use efficiency (Fig. 1b), with L. californica, A. heterophylla, and P. erecta exhibiting high RGR and low WUE typical of a resource acquisition strategy, and $C$. purpurea, $C$. pauciflora, and $H$. congesta displaying low RGR and high WUE typical of resource conservation.

In this system, these two strategies are also correlated with phenological differences. All annuals germinate upon the onset of rains in the late fall/early winter (November-December). Resource-acquisitive forbs generally flower in the spring (April-May) to complete their life cycle before the onset of summer drought and have been referred to as cool- or earlyseason annuals. Resource-conservative forbs survive well into the summer drought period, flowering JuneAugust, and are often referred to as warm- or lateseason annuals (Dyer and Rice 1999; Hooper and Dukes 2010). In comparison, most grasses flower with resource acquisitive forbs, though T. caput-medusae and L. multiflorum flower later than resource acquisitive forbs but prior to resource conservative forbs (May-June).

\section{Demographic data collection}

In October, prior to the first significant rainfall event, I sowed 100 seeds by weight of each native forb species into each subplot, with the exception of $C$. pauciflora and $H$. congesta, which were seeded at 67 seeds per subplot due to seed availability. There was minimal variability in seed number between subplots confirmed by counting a random sampling of prepared seed packets prior to sowing. I recorded germination before thinning all subplots to $\leq 20$ individuals per native forb species to keep plant densities below natural levels and limit density dependent effects. Each subplot therefore had no more than 120 forb individuals. I visited subplots monthly (November through August) to monitor for mortality. During peak flowering for each species, I recorded number of flowers on 5 individuals per species (unless fewer survived) and counted seeds on up to 30 flowers per species in each subplot. I multiplied these means to estimate seed set per individual in each subplot.

To estimate belowground seed survival for my calculation of per capita growth rates, I filled mesh bags with sand plus 100 seeds by weight for each species, except for $C$. pauciflora and $H$. congesta which were again seeded at 67 seeds per bag, and buried them 5-10 $\mathrm{cm}$ belowground in each plot prior to the onset of fall rains (September 2016). I dug up the 
bags the following summer (August 2017) and inspected embryos under a dissecting scope to count number of survived viable seeds (Baskin and Baskin 2014). This measure of seed survival assumes that annual survival rates do not change with seed age. To adjust germination rates, seed set, and pre-burial belowground seed survival for seed viability, I conducted germination trials in a growth chamber and inspected embryo health of non-germinated seeds under a dissecting scope (Baskin and Baskin 2014).

Analyses

I calculated per capita population growth rates $(\lambda)$ per species in each subplot using the following annual plant model, adapted from Levine et al. (2008):

$\lambda=s(1-g)+g(1-m) F$

where $s$ is the annual seed survival rate, $g$ is the proportion of germinated seeds, $m$ is the mortality rate, and $F$ is the seed set, or the number of viable seeds produced per survived germinant. The first term describes the seed bank's contribution to the annual per capita growth rate while the second term represents the per seed production of survived individuals aboveground. All parameters were measured at the subplot (i.e. treatment) level with the exception of seed survival, which was measured at the plot level.

To test how invasive grasses and their litter affected the relative success of resource-acquisitive and resource-conservative native forbs, I investigated changes in $\lambda$ using linear mixed effect models. This model, as well as all subsequent models, included grass treatment ("no grass, no litter", "live grass, no litter", "live grass + litter"), forb functional strategy (acquisitive, conservative), and their interaction as predictors as well as a random intercept for species nested within plot. Values of $\lambda$ were $\log$-transformed after adding a small constant to meet assumptions of normality

To test whether the effects of grass competition and litter on $\lambda$ varied across life stages, I compared changes in germination, mortality, and seed set. For germination, I used a beta-binomial distribution due to overdispersion with number germinated defining a success and the difference between number of seeds sown and number germinated defining a failure. Because the "live grass, no litter" and "no grass, no litter" subplots were similarly free of grass at the beginning of the experiment, I included only two levels for grass treatment in this model, "no grass, no litter" and "live grass + litter", however note that there is no live grass present in the latter treatment at this time and results of this model therefore only explain the effects of litter. For mortality, I used a generalized linear mixed effect model with a binomial response variable with number dead defining successes and number survived defining failures. For seed set, I used a linear mixed effect model on logtransformed values after adding a small constant to meet assumptions of normality.

All data analyses were done in $\mathrm{R}$ version 3.4.4 ( $\mathrm{R}$ Core Team 2018) using the lme4 package (Bates et al. 2015) and the glmmTMB package (Brooks et al. 2017). I used likelihood ratio tests comparing each model with and without the interaction between strategy and grass treatment to determine whether the effect of invasive grass treatment varied by resource acquisition strategy. I then conducted multiple comparisons using the glht function in the multcomp package to test for differences between treatment levels (Hothorn et al. 2008). $P$ values were adjusted using Benjamini-Hochberg corrections (Benjamini and Hochberg 1995).

\section{Results}

As predicted, the effect of grass treatment on per capita population growth rates varied by the resource acquisition strategy of the native forb $\left(\chi^{2}=17.0\right.$, $p<0.001$ ), with invasive grasses in general having a stronger effect on acquisitive forb population growth rates than on conservative forb population growth rates (Fig. 2). Live grass without litter reduced acquisitive population growth rates by $31.1 \%$ ( $p=0.048$ ), while having a non-significant effect on conservative population growth rates $(-0.6 \%$, $p=0.542$ ). The presence of litter had a significantly stronger effect than live grass alone on native forbs of both strategies, but with stronger effects on acquisitives also as predicted (acquisitives: $-73.3 \%$, $p<0.001$; conservatives: $-58.9 \%, p=0.003$ ).

As there was no live grass at the start of the growing season, only the effects of litter can be assessed on germination. Litter alone differentially affected acquisitive and conservative germination $\left(\chi^{2}=8.1\right.$, $p=0.004)$. Germination of both strategies decreased 
in the presence of litter (Fig. 3a), and the effect was stronger for forbs with the resource-acquisitive strategy $(-40.0 \%, p<0.001)$ than for forbs with the resource-conservative strategy $(-24.9 \%, p=0.007)$.

Litter presence in the "live grass + litter" treatment reinforced the differential effects of live invasive grasses on acquisitive per capita growth rates through seed set $\left(\chi^{2}=11.6, p=0.003\right)$, but not through mortality $\left(\chi^{2}=0.38, p=0.823\right)$. Seed set in resource-acquisitive forbs decreased with live grass $(-26.5 \%, p=0.050$; Fig. 3b), while the seed set of resource-conservative forbs did not significantly change $(1.1 \%, p=0.910)$. With the addition of litter, acquisitive seed set significantly decreased even more $(-50.2 \%, p=0.001)$, while conservative seed set did not significantly change $(-16.5 \%, p=0.857)$. In both groups, mortality was unaffected by live grass alone $(p=0.139$; acquisitive: $-8.3 \%$, conservative: $-3.1 \%)$ and increased with the addition of litter ( $p<0.001$; acquisitive: $139.8 \%$, conservative: 38.9\%; Fig. 3c).

For species-specific responses, model output, and post-hoc comparisons see Online Resource 1.

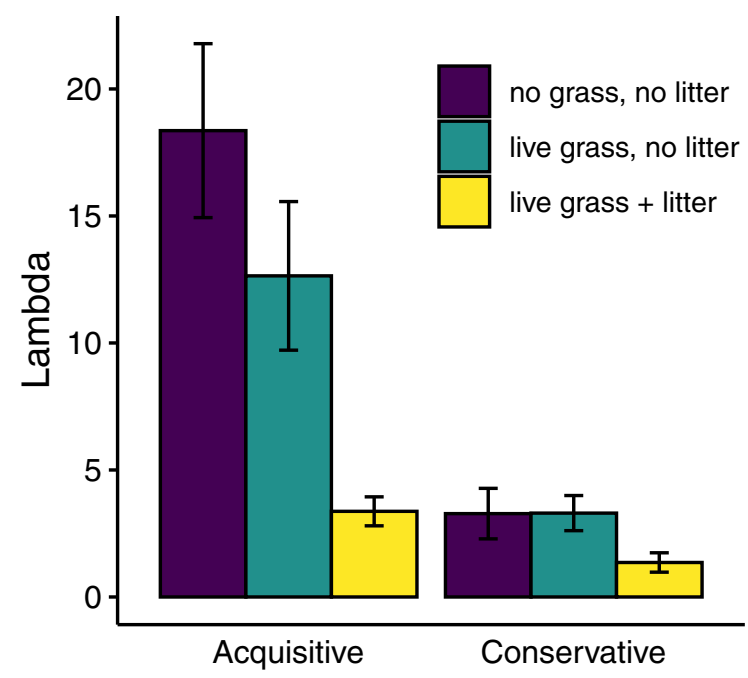

Fig. 2 Per capita population growth rates of resource-acquisitive and resource-conservative native forbs in the "no grass, no litter" (purple), "live grass, no litter" (teal), and "live grass + litter" (yellow) treatments. Error bars show the standard error

\section{Discussion}

This study provides evidence that invasive grass litter can shift the functional composition of native communities by strengthening the effects of live invaders on fast-growing, resource-acquisitive native annual forbs relative to slower-growing, resource-conservative native annual forbs. While live grass competition alone decreased per capita growth rates of acquisitive native forbs and had no effect on conservative native forbs, live grass plus litter led to declines in both types of forbs, but with even stronger declines in those with a resource acquisitive strategy. These findings suggest that resource-sensitive native species may be unable to persist with fast-growing invaders, especially those that produce large quantities of litter. This corroborates studies in invaded water-limited communities that observe higher relative abundances of remnant natives with resource-conservative traits such as deeper roots (Riva et al. 2019), lower SLA (Tordoni et al. 2019), and higher seed mass (Molinari and D'Antonio 2014; Lai et al. 2015). Further, the strong effect of litter combined with live grass emphasizes the importance of investigating the filtering effects of invaders throughout their life cycle, as litter, not competition, may be the dominant biotic driver of changes in functional composition in this system.

The presence of litter decreased the success of acquisitive native forbs more than conservative native forbs through its stronger negative effects on seed set and germination, but not on mortality. The stronger declines in acquisitive seed set may have been due to the low light conditions beneath the litter, which would be particularly challenging for species with shade intolerance (Bennett et al. 2014; Stotz et al. 2019), a trait correlated with fast growth (Reich et al. 1998; Ryser and Wahl 2001). Litter also limited germination more strongly in acquisitives, consistent with lower germination under litter in fast-growing species with smaller seeds (Amatangelo et al. 2008; Loydi et al. 2015; Chen et al. 2018) likely due to their higher light requirements for germination (Milberg et al. 2000). Though the effect of litter addition on mortality did not vary by strategy, with higher replication the effect may be stronger for acquisitives given the large difference in observed effect sizes between the two strategies.

Invasive grasses and their litter had more moderate negative effects on resource-conservative forbs, which 

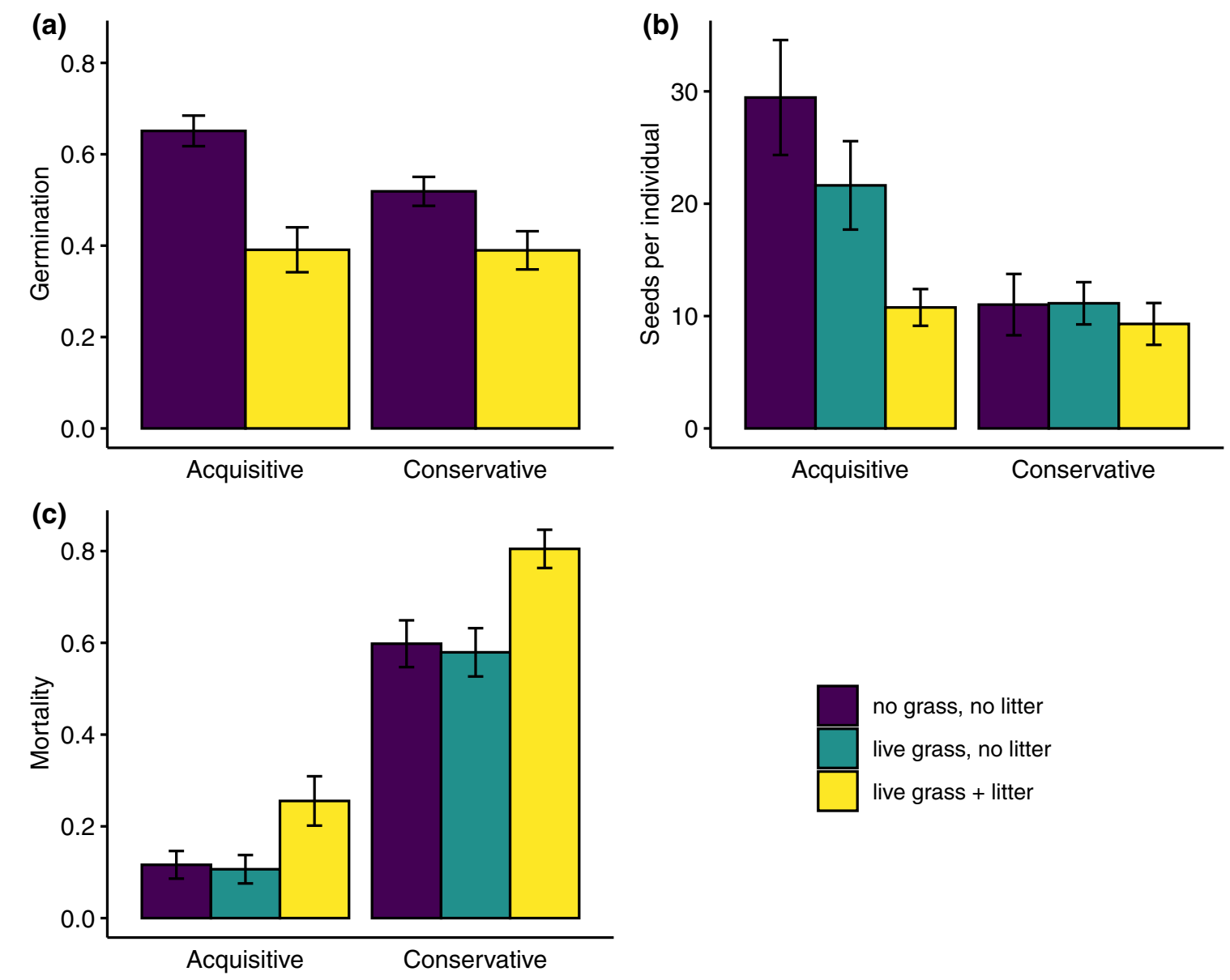

Fig. 3 a Proportion of seeds germinated, b seed set per individual, and $\mathbf{c}$ proportion of seedlings that died in resourceacquisitive and resource conservative native forbs within the "no grass, no litter" (purple), "live grass, no litter" (teal), and "live grass + litter" (yellow) treatments. Note that there is no

were unaffected by live grass competition but declined in the presence of litter, albeit less than acquisitive forbs. This adds to evidence that resource-conservative plants tend to be more tolerant of low resource supply rates, even those induced by competition (Goldberg and Landa 1991, Chapin et al. 1993, but see Liancourt et al. 2005). Further, in this waterlimited system, resource conservation is often associated with deeper roots, later flowering phenology, and lower specific leaf area. These traits have been shown to confer a fitness advantage (Godoy and Levine 2014; Kraft et al. 2015) and may promote coexistence with faster-growing, earlier-developing grasses (MacDougall et al. 2009; Kraft et al. 2015). Litter, however, disrupts this advantage by limiting germination and

"live grass, no litter" treatment for germination as there is no live grass present at the beginning of the growing season; the "live grass + litter" treatment therefore reflects only the effect of litter. Error bars show the standard error

increasing mortality, thereby allowing invaders to dominate over conservative forbs in addition to acquisitive forbs.

While litter combined with live grass affected multiple life stages in both strategies, live grass alone affected only seed set and did so only in acquisitives. This limited effect of live grass likely resulted in part from the study taking place during a wet year, which may have alleviated competition for water between invasive grasses and native forbs. During a drought year, the effects of live grass on acquisitives may be amplified relative to conservatives, such as was found under experimental drought (LaForgia et al. 2020). The wet year may have also played a role in responses to the presence of litter. Generally, litter has been 
shown to have stronger negative effects under more mesic conditions (Xiong and Nilsson 1999; Loydi et al. 2013), which might intensify effects on shade intolerant acquisitives. Conversely, during dry years, the shading and moisture-trapping effects of litter may actually enhance germination and seedling survival (Maestre et al. 2009; Loydi et al. 2013; Wainwright et al. 2017). Whether the positive effects of litter on moisture availability outweigh the negative effects of shade and live competition for acquisitives in these dry years is unknown.

Although I cannot rule out other pathways, I speculate that the differential responses observed in acquisitive and conservative forbs are due to litter's physical effect on the light environment (Facelli and Pickett 1991). This is in line with numerous other studies in this system that found light to be the primary pathway by which litter affects natives (Coleman and Levine 2007; Amatangelo et al. 2008; Chen et al. 2018; Molinari and D'Antonio 2020) and that found negligible leachate effects from grass litter (Amatangelo et al. 2008; Chen et al. 2018). Additionally, changes in nutrient availability due to litter decomposition should affect competitive dynamics between live individuals, but here I found no effects of litter on grass cover, only on native forbs. It is therefore unlikely that these pathways contributed to differential effects. More likely, litter acted as a mechanical barrier to germination and growth (Facelli and Pickett 1991), and this could have contributed to stronger effects on acquisitives that focus on aboveground growth earlier in the season to complete their life cycle when litter is relatively thicker. Regardless of the specific mechanism, however, the present study provides novel evidence that the effects of invasive grasses and their litter are not equally distributed across the native annual community and that the presence of litter may give invasive grasses an edge over conservative forbs.

Resource-acquisitive native forbs, which rely on high rainfall years to replenish their populations (Huxman et al. 2008), contribute disproportionately to variation in diversity among years (Elmendorf and Harrison 2009; Fernandez-Going et al. 2012; Harrison et al. 2018). By harming acquisitive species, invasive grasses may be diminishing the responsiveness of grassland systems to annual climatic variation, with possible effects on important resource pulses for pollinators (Potts et al. 2003; Ebeling et al. 2008) and other invertebrates (Suttle et al. 2007). Disturbances that decrease litter, such as grazing, fire, and prolonged drought, should help alleviate these effects, leading to higher diversity and abundance (Levine and Rees 2002; Harrison et al. 2003; Young et al. 2015; Beck et al. 2015; LaForgia et al. 2018).

These results add to growing evidence that invasive grass dominance over native forbs may be driven predominantly by their litter (Amatangelo et al. 2008; Molinari and D'Antonio 2020). This litter acts as a filter on the native community through its persistent effects on multiple forb life stages, increasing the advantage of resource-conservative over resourceacquisitive forbs. The capacity for acquisitive forbs to continue to replenish their populations in wet years following litter removal is likely limited given the expected decrease in precipitation in California (Diffenbaugh et al. 2015) and temperate grasslands in general (Gherardi and Sala 2019). Interestingly, without litter, invaders may not be dominant over conservative forbs, highlighting that pathways of dominance might vary across natives. In our quest to mitigate the harmful effects of invasive species, it is therefore critical to consider the various pathways by which invaders change the shared environment, as pathways other than competition have the potential to significantly shift the functional composition of native communities.

Acknowledgements I thank Susan Harrison, Andrew Latimer, and Jennifer Gremer for their valuable discussions and feedback on this manuscript. I also thank the Donald and Sylvia McLaughlin UC Natural Reserve and its directors, Cathy Koehler and Paul Aigner, for their support along with numerous UC Davis undergraduates who helped process data and samples.

Funding This study was funded by the Davis Botanical Society. LaForgia was supported by an NSF GRFP.

Data availability Data are publicly available via GitHub: https://github.com/marinalaforgia/McL_Thatch-effects.

Code availability No custom softwares or code was used for the project.

\section{Declarations}

Conflict of interest The author declares that she has no conflict of interest.

Consent to participate Not applicable. 
Consent for publication I consent for this to be published.

Ethics approval Not applicable.

Open Access This article is licensed under a Creative Commons Attribution 4.0 International License, which permits use, sharing, adaptation, distribution and reproduction in any medium or format, as long as you give appropriate credit to the original author(s) and the source, provide a link to the Creative Commons licence, and indicate if changes were made. The images or other third party material in this article are included in the article's Creative Commons licence, unless indicated otherwise in a credit line to the material. If material is not included in the article's Creative Commons licence and your intended use is not permitted by statutory regulation or exceeds the permitted use, you will need to obtain permission directly from the copyright holder. To view a copy of this licence, visit http://creativecommons.org/licenses/by/4.0/.

\section{References}

Amatangelo KL, Dukes JS, Field CB (2008) Responses of a California annual grassland to litter manipulation. J Veg Sci 19:605-612. https://doi.org/10.3170/2008-8-18415

Angert AL, Huxman TE, Barron-Gafford GA et al (2007) Linking growth strategies to long-term population dynamics in a guild of desert annuals. J Ecol 95:321-331

Angert AL, Huxman TE, Chesson P, Venable DL (2009) Functional tradeoffs determine species coexistence via the storage effect. Proc Natl Acad Sci USA 106:11641-11645. https://doi.org/10.1073/pnas.0904512106

Bartolome JW (1979) Germination and seedling establishment in California annual grassland. J Ecol 67:273-281. https:// doi.org/10.2307/2259350

Baskin CC, Baskin JM (2014) Ecologically meaningful germination studies. In: Baskin CC, Baskin JM (eds) Seeds: ecology, biogeography, and, evolution of dormancy and germination, 2nd edn. Academic Press, San Diego, pp 5-35

Bates D, Mächler M, Bolker B, Walker S (2015) Fitting linear mixed-effects models using lme4. J Stat Softw 67:1-48. https://doi.org/10.18637/jss.v067.i01

Beck JJ, Hernandez DL, Pasari JR, Zavaleta ES (2015) Grazing maintains native plant diversity and promotes community stability in an annual grassland. Ecol Appl 25:1259-1270. https://doi.org/10.1890/14-1093.1

Benjamini Y, Hochberg Y (1995) Controlling the false discovery rate: a practical and powerful approach to multiple testing. J R Stat Soc Ser B (Methodol) 57:289-300

Bennett JA, Stotz GC, Cahill JF (2014) Patterns of phylogenetic diversity are linked to invasion impacts, not invasion resistance, in a native grassland. J Veg Sci 25:1315-1326. https://doi.org/10.1111/jvs.12199

Brooks ME, Kristensen K, van Benthem KJ et al (2017) glmmTMB balances speed and flexibility among packages for zero-inflated generalized linear mixed modeling. R J 9:378-400
Brown JS, Venable DL (1986) Evolutionary ecology of seedbank annuals in temporally varying environments. Am Nat 127:31-47. https://doi.org/10.1086/284465

Carmona CP, de Bello F, Azcárate FM et al (2019) Trait hierarchies and intraspecific variability drive competitive interactions in Mediterranean annual plants. J Ecol 107:2078-2089. https://doi.org/10.1111/1365-2745.13248

Case EJ, Harrison S, Cornell HV (2016) Do high-impact invaders have the strongest negative effects on abundant and functionally similar resident species? Funct Ecol 30:1447-1453. https://doi.org/10.1111/1365-2435.12615

Chapin FS, Autumn K, Pugnaire F (1993) Evolution of suites of traits in response to environmental stress. Am Nat 142:S78-S92

Chen B-M, D'Antonio CM, Molinari N, Peng S-L (2018) Mechanisms of influence of invasive grass litter on germination and growth of coexisting species in California. Biol Invasions 20:1881-1897. https://doi.org/10.1007/ s10530-018-1668-5

Cleland EE, Larios L, Suding KN (2013) Strengthening invasion filters to reassemble native plant communities: soil resources and phenological overlap. Restor Ecol 21:390-398. https://doi.org/10.1111/j.1526-100X.2012. 00896.x

Coleman HM, Levine JM (2007) Mechanisms underlying the impacts of exotic annual grasses in a coastal California meadow. Biol Invasions 9:65-71. https://doi.org/10.1007/ s10530-006-9008-6

Corbin JD, D'Antonio CM (2010) Not novel, just better: competition between native and non-native plants in California grasslands that share species traits. Plant Ecol 209:71-81. https://doi.org/10.1007/s11258-010-9722-0

Cornwell WK, Cornelissen JHC, Amatangelo K et al (2008) Plant species traits are the predominant control on litter decomposition rates within biomes worldwide. Ecol Lett 11:1065-1071. https://doi.org/10.1111/j.1461-0248.2008. 01219.x

D’Antonio CM, Vitousek PM (1992) Biological invasions by exotic grasses, the grass fire cycle, and global change. Annu Rev Ecol Syst 23:63-87. https://doi.org/10.1146/ annurev.ecolsys.23.1.63

da Silva ER, da Silveira LHR, Overbeck GE, Soares GLG (2018) Inhibitory effects of Eucalyptus saligna leaf litter on grassland species: physical versus chemical factors. Plant Ecolog Divers 11:55-67. https://doi.org/10.1080/ 17550874.2018.1474393

Davies KW (2011) Plant community diversity and native plant abundance decline with increasing abundance of an exotic annual grass. Oecologia 167:481-491. https://doi.org/10. 1007/s00442-011-1992-2

Dawson TE, Mambelli S, Plamboeck AH et al (2002) Stable isotopes in plant ecology. Annu Rev Ecol Syst 33:507-559. https://doi.org/10.1146/annurev.ecolsys.33. 020602.095451

de la Riva EG, Godoy O, Castro-Díez P et al (2019) Functional and phylogenetic consequences of plant invasion for coastal native communities. J Veg Sci 30:510-520. https:// doi.org/10.1111/jvs. 12748

Diaz S, Hodgson JG, Thompson K et al (2004) The plant traits that drive ecosystems: evidence from three continents. 
J Veg Sci 15:295-304. https://doi.org/10.1111/j.16541103.2004.tb02266.x

Diffenbaugh NS, Swain DL, Touma D (2015) Anthropogenic warming has increased drought risk in California. Proc Natl Acad Sci 112:3931-3936. https://doi.org/10.1073/pnas. 1422385112

Dyer AR, Rice KJ (1999) Effects of competition on resource availability and growth of a California bunchgrass. Ecology 80:2697-2710. https://doi.org/10.1890/00129658(1999)080[2697:eocora]2.0.co;2

Ebeling A, Klein A-M, Schumacher J et al (2008) How does plant richness affect pollinator richness and temporal stability of flower visits? Oikos 117:1808-1815. https://doi. org/10.1111/j.1600-0706.2008.16819.x

Ehrenfeld JG (2003) Effects of exotic plant invasions on soil nutrient cycling processes. Ecosystems 6:503-523. https:// doi.org/10.1007/s10021-002-0151-3

Ehrenfeld JG (2010) Ecosystem Consequences of Biological Invasions. Annu Rev Ecol Evol Syst 41:59-80. https://doi. org/10.1146/annurev-ecolsys-102209-144650

Elmendorf SC, Harrison SP (2009) Temporal variability and nestedness in California grassland species composition. Ecology 90:1492-1497. https://doi.org/10.1890/08-1677.1

Emery SM (2007) Limiting similarity between invaders and dominant species in herbaceous plant communities? J Ecol 95:1027-1035. https://doi.org/10.1111/j.1365-2745.2007. 01274.x

Facelli JM, Pickett STA (1991) Plant litter: Its dynamics and effects on plant community structure. Bot Rev 57:1-32. https://doi.org/10.1007/BF02858763

Fargione J, Tilman D (2005) Niche differences in phenology and rooting depth promote coexistence with a dominant $\mathrm{C}-4$ bunchgrass. Oecologia 143:598-606. https://doi.org/10. 1007/s00442-005-0010-y

Fargione J, Brown CS, Tilman D (2003) Community assembly and invasion: an experimental test of neutral versus niche processes. Proc Natl Acad Sci USA 100:8916-8920

Farrer EC, Goldberg DE (2009) Litter drives ecosystem and plant community changes in cattail invasion. Ecol Appl 19:398-412. https://doi.org/10.1890/08-0485.1

Fernandez-Going BM, Anacker BL, Harrison SP (2012) Temporal variability in California grasslands: soil type and species functional traits mediate response to precipitation. Ecology 93:2104-2114

Franck VM, Hungate BA, Chapin FS, Field CB (1997) Decomposition of litter produced under elevated $\mathrm{CO}_{2}$ : dependence on plant species and nutrient supply. Biogeochemistry 36:223-237. https://doi.org/10.1023/A: 1005705300959

Gherardi LA, Sala OE (2019) Effect of interannual precipitation variability on dryland productivity: a global synthesis. Glob Change Biol 25:269-276. https://doi.org/10.1111/ gcb. 14480

Godoy O, Levine JM (2014) Phenology effects on invasion success: insights from coupling field experiments to coexistence theory. Ecology 95:726-736. https://doi.org/ 10.1890/13-1157.1

Goldberg DE (1996) Competitive ability: definitions, contingency and correlated traits. Philos Trans Biol Sci 351:1377-1385
Goldberg DE, Landa K (1991) Competitive effect and response: hierarchies and correlated traits in the early stages of competition. J Ecol 79:1013-1030. https://doi.org/10. 2307/2261095

Gubsch M, Buchmann N, Schmid B et al (2011) Differential effects of plant diversity on functional trait variation of grass species. Ann Bot 107:157-169. https://doi.org/10. 1093/aob/mcq220

Harrison S, LaForgia M (2019) Seedling traits predict droughtinduced mortality linked to diversity loss. PNAS. https:// doi.org/10.1073/pnas.1818543116

Harrison SP, Inouye BD, Safford HD (2003) Ecological heterogeneity in the effects of grazing and fire on grassland diversity. Conserv Biol 17:837-845. https://doi.org/10. 1046/j.1523-1739.2003.01633.x

Harrison SP, LaForgia ML, Latimer AM (2018) Climate-driven diversity change in annual grasslands: drought plus deluge does not equal normal. Glob Change Biol 24:1782-1792. https://doi.org/10.1111/gcb.14018

Heady HF (1956) Changes in a California annual plant community induced by manipulation of natural mulch. Ecology 37:798-812. https://doi.org/10.2307/1933071

Hooper DU, Dukes JS (2010) Functional composition controls invasion success in a California serpentine grassland. J Ecol 98:764-777. https://doi.org/10.1111/j.1365-2745. 2010.01673.x

Hothorn T, Bretz F, Westfall P (2008) Simultaneous inference in general parametric models. Biom J 50:346-363. https:// doi.org/10.1002/bimj.200810425

Huenneke LF, Hamburg SP, Koide R et al (1990) Effects of soil resources on plant invasion and community structure in californian serpentine Grassland. Ecology 71:478-491. https://doi.org/10.2307/1940302

Huxman TE, Barron-Gafford G, Gerst KL et al (2008) Photosynthetic resource-use efficiency and demographic variability in desert winter annual plants. Ecology 89:1554-1563. https://doi.org/10.1890/06-2080.1

Kimball S, Gremer JR, Angert AL et al (2012) Fitness and physiology in a variable environment. Oecologia 169:319-329. https://doi.org/10.1007/s00442-011-2199-2

Kraft NJB, Godoy O, Levine JM (2015) Plant functional traits and the multidimensional nature of species coexistence. Proc Natl Acad Sci 112:797-802. https://doi.org/10.1073/ pnas. 1413650112

LaForgia ML, Spasojevic MJ, Case EJ et al (2018) Seed banks of native forbs, but not exotic grasses, increase during extreme drought. Ecology. https://doi.org/10.1002/ecy. 2160

LaForgia ML, Harrison SP, Latimer AM (2020) Invasive species interact with climatic variability to reduce success of natives. Ecology. https://doi.org/10.1002/ecy.3022

Lagos ME, White CR, Marshall DJ (2017) Do invasive species live faster? Mass-specific metabolic rate depends on growth form and invasion status. Funct Ecol 31:2080-2086. https://doi.org/10.1111/1365-2435.12913

Lai HR, Mayfield MM, Gay-des-combes JM et al (2015) Distinct invasion strategies operating within a natural annual plant system. Ecol Lett 18:336-346. https://doi.org/10. 1111/ele.12414 
Lamb EG (2008) Direct and indirect control of grassland community structure by litter, resources, and biomass. Ecology 89:216-225. https://doi.org/10.1890/07-0393.1

Lavorel S, Garnier E (2002) Predicting changes in community composition and ecosystem functioning from plant traits: revisiting the Holy Grail. Funct Ecol 16:545-556. https:// doi.org/10.1046/j.1365-2435.2002.00664.x

Leishman MR, Haslehurst T, Ares A, Baruch Z (2007) Leaf trait relationships of native and invasive plants: communityand global-scale comparisons. New Phytol 176:635-643. https://doi.org/10.1111/j.1469-8137.2007.02189.x

Levine JM, Rees M (2002) Coexistence and relative abundance in annual plant assemblages: the roles of competition and colonization. Am Nat 160:452-467. https://doi.org/10. 1086/342073

Levine JM, Vila M, D’Antonio CM et al (2003) Mechanisms underlying the impacts of exotic plant invasions. Proc R Soci B Biol Sci 270:775-781. https://doi.org/10.1098/rspb. 2003.2327

Levine JM, McEachern AK, Cowan C (2008) Rainfall effects on rare annual plants. J Ecol 96:795-806. https://doi.org/10. 1111/j.1365-2745.2008.01375.x

Liancourt P, Callaway RM, Michalet R (2005) Stress tolerance and competitive-response ability determine the outcome of biotic interactions. Ecology 86:1611-1618. https://doi.org/ 10.1890/04-1398

Loydi A, Eckstein RL, Otte A, Donath TW (2013) Effects of litter on seedling establishment in natural and semi-natural grasslands: a meta-analysis. J Ecol 101:454-464. https:// doi.org/10.1111/1365-2745.12033

Loydi A, Donath TW, Eckstein RL, Otte A (2015) Non-native species litter reduces germination and growth of resident forbs and grasses: allelopathic, osmotic or mechanical effects? Biol Invasions 17:581-595. https://doi.org/10. 1007/s10530-014-0750-x

MacDougall AS, Gilbert B, Levine JM (2009) Plant invasions and the niche. J Ecol 97:609-615. https://doi.org/10.1111/ j.1365-2745.2009.01514.x

MacGillivray CW, Grime JP, Team TISP (ISP) (1995) Testing predictions of the resistance and resilience of vegetation subjected to extreme events. Funct Ecol 9:640-649. https:// doi.org/10.2307/2390156

Mack RN, Simberloff D, Lonsdale WM et al (2000) Biotic invasions: causes, epidemiology, global consequences, and control. Ecol Appl 10:689-710. https://doi.org/10.2307/ 2641039

Maestre FT, Callaway RM, Valladares F, Lortie CJ (2009) Refining the stress-gradient hypothesis for competition and facilitation in plant communities. J Ecol 97:199-205. https://doi.org/10.1111/j.1365-2745.2008.01476.x

Mariotte P, Spotswood EN, Farrer EC, Suding KN (2017) Positive litter feedbacks of an introduced species reduce native diversity and promote invasion in Californian grasslands. Appl Veg Sci 20:28-39. https://doi.org/10. 1111/avsc. 12291

Milberg P, Andersson L, Thompson K (2000) Large-seeded species are less dependent on light for germination than small-seeded ones. Seed Sci Res 10:99-104. https://doi. org/10.1017/S0960258500000118
Miriti MN (2006) Ontogenetic shift from facilitation to competition in a desert shrub. J Ecol 94:973-979. https://doi. org/10.1111/j.1365-2745.2006.01138.x

Mitchell RM, Bakker JD (2016) Grass abundance shapes trait distributions of forbs in an experimental grassland. J Veg Sci 27:557-567. https://doi.org/10.1111/jvs.12389

Molinari NA, D'Antonio CM (2014) Structural, compositional and trait differences between native- and non-nativedominated grassland patches. Funct Ecol 28:745-754. https://doi.org/10.1111/1365-2435.12206

Molinari NA, D'Antonio CM (2020) Where have all the wildflowers gone? The role of exotic grass thatch. Biol Invasions 22:957-968. https://doi.org/10.1007/s10530-01902135-1

Paine CET, Marthews TR, Vogt DR et al (2012) How to fit nonlinear plant growth models and calculate growth rates: an update for ecologists. Methods Ecol Evol 3:245-256. https://doi.org/10.1111/j.2041-210X.2011.00155.x

Potts SG, Vulliamy B, Dafni A et al (2003) Linking bees and flowers: how do floral communities structure pollinator communities? Ecology 84:2628-2642. https://doi.org/10. 1890/02-0136

Price JN, Pärtel M (2013) Can limiting similarity increase invasion resistance? A meta-analysis of experimental studies. Oikos 122:649-656. https://doi.org/10.1111/j. 1600-0706.2012.00121.x

R Core Team (2018) R: a language and environment for statistical computing. R Foundation for Statistical Computing, Vienna

Reich PB (2014) The world-wide 'fast-slow' plant economics spectrum: a traits manifesto. J Ecol 102:275-301. https:// doi.org/10.1111/1365-2745.12211

Reich PB, Tjoelker MG, Walters MB et al (1998) Close association of RGR, leaf and root morphology, seed mass and shade tolerance in seedlings of nine boreal tree species grown in high and low light. Funct Ecol 12:327-338. https://doi.org/10.1046/j.1365-2435.1998.00208.x

Richardson DM, Pysek P (2006) Plant invasions: merging the concepts of species invasiveness and community invasibility. Prog Phys Geogr 30:409-431. https://doi.org/10. 1191/0309133306pp490pr

Rotundo JL, Aguiar MR (2005) Litter effects on plant regeneration in arid lands: a complex balance between seed retention, seed longevity and soil-seed contact. J Ecol 93:829-838. https://doi.org/10.1111/j.1365-2745.2005. 01022.x

Ryser P, Wahl S (2001) Interspecific variation in RGR and the underlying traits among 24 grass species grown in full daylight. Plant Biol 3:426-436. https://doi.org/10.1055/s2001-16460

Schiffers K, Tielborger K (2006) Ontogenetic shifts in interactions among annual plants. J Ecol 94:336-341. https://doi. org/10.1111/j.1365-2745.2006.01097.x

Schramm JW, Ehrenfeld JG (2010) Leaf litter and understory canopy shade limit the establishment, growth and reproduction of Microstegium vimineum. Biol Invasions 12:3195-3204. https://doi.org/10.1007/s10530-010-97111

Schultheis EH, MacGuigan DJ (2018) Competitive ability, not tolerance, may explain success of invasive plants over 
natives. Biol Invasions 20:2793-2806. https://doi.org/10. 1007/s10530-018-1733-0

Stotz GC, Gianoli E, Cahill JF (2019) Biotic homogenization within and across eight widely distributed grasslands following invasion by Bromus inermis. Ecology. https://doi. org/10.1002/ecy.2717

Suttle KB, Thomsen MA, Power ME (2007) Species interactions reverse grassland responses to changing climate. Science 315:640-642. https://doi.org/10.1126/science. 1136401

Tordoni E, Petruzzellis F, Nardini A et al (2019) Make it simpler: Alien species decrease functional diversity of coastal plant communities. J Veg Sci 30:498-509. https://doi.org/ $10.1111 /$ jvs. 12734

van Kleunen M, Weber E, Fischer M (2010) A meta-analysis of trait differences between invasive and non-invasive plant species. Ecol Lett 13:235-245. https://doi.org/10.1111/j. 1461-0248.2009.01418.x

Violle C, Richarte J, Navas M-L (2006) Effects of litter and standing biomass on growth and reproduction of two annual species in a Mediterranean old-field. $J$ Ecol 94:196-205. https://doi.org/10.1111/j.1365-2745.2005. 01061.x

Vitousek PM, D’Antonio CM, Loope LL et al (1997) Introduced species: a significant component of human-caused global change. N Z J Ecol 21:1-16

Wainwright CE, Dwyer JM, Mayfield MM (2017) Effects of exotic annual grass litter and local environmental gradients on annual plant community structure. Biol Invasions 19:479-491. https://doi.org/10.1007/s10530-016-1303-2

Westoby M, Falster DS, Moles AT et al (2002) Plant ecological strategies: some leading dimensions of variation between species. Annu Rev Ecol Syst 33:125-159. https://doi.org/ 10.1146/annurev.ecolsys.33.010802.150452

Wolkovich EM, Bolger DT, Cottingham KL (2009) Invasive grass litter facilitates native shrubs through abiotic effects. J Veg Sci 20:1121-1132

Wright IJ, Reich PB, Westoby M et al (2004) The worldwide leaf economics spectrum. Nature 428:821-827. https://doi. org/10.1038/nature02403

Xiong S, Nilsson C (1999) The effects of plant litter on vegetation: a meta-analysis. J Ecol 87:984-994. https://doi.org/ 10.1046/j.1365-2745.1999.00414.x

Young DJN, Porensky LM, Wolf KM et al (2015) Burning reveals cryptic plant diversity and promotes coexistence in a California prairie restoration experiment. Ecosphere 6:art81. https://doi.org/10.1890/ES14-00303.1

Zhang P, Li B, Wu J, Hu S (2019) Invasive plants differentially affect soil biota through litter and rhizosphere pathways: a meta-analysis. Ecol Lett 22:200-210. https://doi.org/10. 1111/ele.13181

Publisher's Note Springer Nature remains neutral with regard to jurisdictional claims in published maps and institutional affiliations. 